\title{
Pengaruh Persepsi Kualitas Produk, Merek dan Layanan Purna Jual Terhadap Keputusan Pembelian Skuter Metik Merek Honda di Kota Banda Aceh
}

\author{
Jufidar $^{1 *}$, Fakhrurrazi Abbas ${ }^{1}$, Irwan Safwadi ${ }^{2}$ \\ ${ }^{1}$ Program Studi Manajemen, Fakultas Ekonomi, Universitas Abulyatama, Aceh Besar, 23372, \\ Indonesia. \\ ${ }^{2}$ Program Studi Ekonomi Pembangunan, Fakultas Ekonomi, Universitas Abulyatama, Aceh Besar, \\ 23372, Indonesia. \\ *Email korespondensi: jufidat.pg@gmail.com
}

\begin{abstract}
Diterima 21 Desember 2018; Disetujui 1 April 2019; Dipublikasi 31 Oktober 2018
Abstract: This research is an empirical study which aims to determine the effect of perceptions of product quality, brand and after-sales service on the decision to purchase Honda brand metic scooters in Banda Aceh City either partially or simultaneously. The number of research samples is 381 consumers. Sampling in this study was carried out with a minimum sample formulation using the Slovin method. Data collection is done by distributing question sheets (questionnaires) to respondents. The primary data is then analyzed using multiple linear regression. The results of multiple linear regression analysis can explain that the perception of product quality, brand and after-sales service has a positive effect on the purchase decision of Honda brand metic scooters in Banda Aceh City. The effect of the three variables is significant with a significant probability value $<0.05$. Or, simultaneously the perception of product quality, brand, and after-sales service has a strong and positive relationship with the decision to purchase Honda brand metic scooters in Banda Aceh City in Banda Aceh City. The role of perceptions of product quality, brand and after-sales service in influencing the decision to purchase Honda brand metic scooters in Banda Aceh is still less dominant with R2 of 0.386 .
\end{abstract}

\section{Keywords: perception of product quality, brand and after-sales service, Purchasing decisions}

\begin{abstract}
Abstrak: Penelitian ini merupakan studi empiris yang bertujuan untuk mengetahui pengaruh persepsi kualitas produk, merek dan layanan purna jual terhadap keputusan pembelian skuter metik merek Honda di Kota Banda Aceh baik secara parsial maupun simultan. Jumlah sampel penelitian adalah sebanyak 381 konsumen. Penarikan sampel dalam penelitian ini dilakukan dengan formulasi sampel minimal dengan menggunakan metode Slovin. Pengumpulan data dilakukan dengan membagikan lembaran pertanyaan (kuesioner) kepada responden. Data primer tersebut selanjutnya dianalisis dengan menggunakn regresi linier berganda. Hasil analisis regresi liner berganda dapat menjelaskan bahwa persepsi kualitas produk, merek dan layanan purna jual berpengaruh positif terhadap keputusan pembelian skuter metik merek Honda di Kota Banda Aceh. Pengaruh ketiga variabel tersebut signifikan dengan nilai probabilitas signifikan $<0,05$. Atau, secara simultan persepsi kualitas produk, merek, dan layanan purna jual memiliki hubungan yang kuat dan positif dengan keputusan pembelian skuter metik merek Honda di Kota Banda Aceh di Kota Banda Aceh. Peran persepsi kualitas produk, merek dan layanan purna jual dalam mempengaruhi keputusan pembelian skuter metik merek Honda di Kota Banda Aceh masih kurang dominan dengan $\mathrm{R}^{2}$ sebesar 0.386 .
\end{abstract}

Kata kunci : Persepsi kualitas produk, merek dan layanan purna jual, keputusan Pembelian. 
Kendaraan roda dua telah menjadi alat transportasi terfavorit di Tanah Air. Meningkatnya jumlah penduduk dan pendapatan perkapita sejalan dengan perubahan gaya hidup masyarakat membuat permintaan kenderaan roda dua terus meningkat setiap tahun. Dari sejumlah kenderaan roda dua yang dipasarkan di tanah air, Honda menjadi salah satu produk terlaris di Indonesia. Berdasarkan Asosiasi Industri Sepeda Motor Indonesia (AISI), penjualan kenderaan merek Honda menjadi penjualan tertinggi di tanah air dengan jumlah penjualan tahun 2017 mencapai 4.385 .888 unit atau mendominasi penjualan nasional dengan persentase 74,51 persen. Di posisi kedua, ditempati Yamaha dengan jumlah penjualan sebanyak 1.348.211 unit atau sekira 22,90 persen jumlah penjualan domestik. Kemudian, yang ketiga ditempati Kawasaki dengan jumlah penjualan sebanyak 97.622 unit atau berkontribusi terhadap penjualan nasional sebesar 1,34 persen (http://otomotif.bisnis.com, diakses 24/03/2018).

Keberhasilan penjualan sepeda motor Honda di Indonesia tidak terlepas dari kepercayaan masyarakat terhadap produk tersebut. Meskipun dalam kondisi ekonomi yang sedang dalam kondisi sulit sekalipun, pembelian sepeda motor Honda terus meningkat. Kondisi ini membuat sepeda motor merek Honda menjadi pemimpin pasar kenderaan roda dua sepanjang sejarah di Indonesia. Kecenderungan tersebut juga terjadi di berbagai daerah di Indonesia termasuk di Kota Banda Aceh.

Meningkatnya pendapatan masyarakat sejalan dengan hadirnya perusahaan dealer/showroom, leasing dan usaha agen roda dua yang menawarkan berbagai bentuk kemudahan dalam pembelian sepeda motor di Kota Banda Aceh telah meningkatlkan minat konsumen untuk membeli produk kendaraan roda dua merek Honda. Saat ini, sepeda motor merek Honda di Kota Banda Aceh seakan menjadi kebutuhan yang semakin primer bagi kebutuhan keluarga. Memiliki sepeda motor merek honda bukan hanya berkaitan dengan masalah prestise semata, namun telah menjadi kebutuhan sarana transportasi utama yang digunakan setiap waktu secara praktis, hemat dan ekonomis. Kondisi tersebut membuat keputusan konsumen untuk membeli kendaraan merek Honda di Kota Banda Aceh sangat tinggi sama tingginya dengan minat terhadap kebutuhan pangan dan sandang.

Keputusan konsumen dalam pembelian sepeda motor merek Honda di Kota Banda Aceh masih didominasi oleh jenis sekuter metik terutama jenis Beat eSP Sporty dengan jumlah penjualan tertinggi. Kemudian di ikuti oleh jenis Vario 125 eSP, Vario 150 eSP, New Scoopy eSP, Beat eSP POP. Jenis kenderaan sekuter matik di Kota Banda Aceh sangat diminati oleh kalangan muda. Dengan demikian, pembelian sepeda motor metik di Kota Banda Aceh secara rasional tidak semata-mata dipengaruhi oleh pertimbangan harga, namun juga oleh kualitas produk, merek dan pelayanan purna jual.

Kualitas produk adalah kemampuan suatu barang maupun jasa untuk memberikan hasil atau kinerja yang sesuai bahkan melebihi 
dari apa yang diinginkan konsumen (Kotler dan Keller, 2012:143). Kualitas produk juga dapat diartikan sebagai kemampuan suatu produk untuk melaksanakan fungsinya, meliputi daya tahan, keandalan, ketepatan, kemudahan operasi dan perbaikan serta atribut bernilai lainnya (Kotler dan Keller, 2012:121). Kualitas merupakan suatu ukuran untuk menilai bahwa suatu barang atau jasa telah mempunyai nilai guna seperti yang dikehendaki (Sunyoto, 2012:231). Dengan memahami kualitas produk dengan baik maka sikap dan keyakinan konsumen terhadap suatu produk akan lebih baik dan kemudian akan dapat mendukung konsumen untuk membuat suatu keputusan pembelian dengan baik.

Motor Honda dikenal oleh konsumen karena keiritan dan daya tahan mesinnya yang berada di atas rata-rata kendaraan merek lainnya. Bahkan dengan teknologi PGM injeksi jaman sekarang, telah mengukuhkan Honda sebagai motor teririt. Hampir seluruh motor keluaran Honda saat ini menggunakan teknologi injeksi PGM FI. PGM FI atau Programmable Fuel Injection yang memungkinkan terjadinya efisiensi pada bahan bakar. Dengan banyak keunggulan, maka sudah tentu membuat Harga jual kembali atau resale value dari sekuter metik motor sangatlah tinggi.

Selain kualitas, merek juga menjadi salah satu kekuatan bagi dealer resmi Honda PT. Capella Dinamika Nusantara Banda Aceh dalam meningkatkan keputusan masyarakat di Kota Banda Aceh dalam membeli sekuter metik merek Honda. Merek (brand) Honda bukan sekedar nama, istilah (term), tanda (sign), simbol atau kombinasi diantaranya, namun lebih dari itu merupakan janji-janji perusahaan yang secara konsisten memberikan kualitas, manfaat (benefit) dan pelayanan (service). Dengan janjijanji inilah para konsumen selalu mengenal dan percaya kepada merek Honda yang diyakini dapat memenuhi kepuasan, harapan dan prestise. Kondisi tersebut telah membuat minat konsumen akan cendrung lebih kuat.

\section{KAJIAN PUSTAKA}

\section{Kualitas Produk}

Kualitas produk merupakan hal penting yang harus diusahakan oleh setiap perusahaan jika ingin yang dihasilkan dapat bersaing di pasar untuk memuaskan kebutuhan dan keininan konsumen. Kualitas produk merupakan bagaimana menggambarkan produk tersebut dapat memberikan sesuatu yang dapat memuaskan konsumen. Menurut Goetsch dan Davis (1994) yang dikutip oleh Tjiptono (2014:152), kualitas dapat diartikan sebagai "kondisi dinamis yang berhubungan dengan produk, jasa, sumber daya manusia, proses, dan lingkungan yang memenuhi atau melebihi harapan".

Kotler dan Keller (2012: 143), menyatakan kualitas produk adalah kemampuan suatu barang untuk memberikan hasil atau kinerja yang sesuai bahkan melebihi dari apa yang diinginkan pelanggan. Lebih lanjut Kotler dan Keller (2012: 121) menjelaskan kualitas produk adalah kemampuan suatu produk untuk melaksanakan fungsinya, meliputi daya tahan, keandalan, ketepatan, kemudahan operasi dan 
perbaikan serta atribut bernilai lainnya.

Menurut Basu Swasta (2009:221) dalam

Yusuf (2015) kualitas produk adalah suatu kondisi dari sebuah barang melalui strategi manajemen yang menggunakan informasi untuk menciptakan suatu kesan terhadap produk sesuai dengan keinginan konsumen. Kotler dan Armstrong (2012 : 230) mendefinisikan "kualitas produk adalah karakteristik suatu produk atau jasa yang menunjang kemampuannya untuk memuaskan kebutuhan pelanggan.

Sunyoto (2012:231) menyatakan bahwa kualitas merupakan suatu ukuran untuk menilai bahwa suatu barang atau jasa telah mempunyai nilai guna seperti yang dikehendaki atau dengan kata lain suatu barang atau jasa dianggap telah memiliki kualitas apabila berfungsi atau mempunyai nilai guna seperti yang diinginkan.

Menurut Kotler (2009:8-10) dalam Yusuf (2015) kualitas produk adalah kemampuan suatu barang untuk memberikan hasil atau kinerja yang sesuai bahkan melebihi dari apa yang telah diinginkan konsumen.

\section{Merek (Brand)}

Sumarwan (2015:303) mendefinisakan merek adalah nama penting bagi sebuah produk atau jasa. Merek adalah simbol dan indikator kualitas dari sebuah produk. Merek-merek produk yang sudah lama dikenal oleh onsumen telah menjadi sebuah citra bahkan symbol status produk tersebut". Merek Menurut American Marketing Association yang dikutip Kotler (2000:460) dalam Cece (2015), merek adalah nama, istilah, tanda, simbol, rancangan atau kombinasi dari seorang atau sekelompok penjual dan untuk membedakan dari produk pesaing.

Kemudian Rangkuti (2002:2) dalam Cece (2015) menjelaskan tujuan pemberian merek adalah untuk mengidentifikasi suatu produk atau jasa yang dihasilkan oleh pesaing. Karakteristik yang kuat dari suatu merek akan sangat membantu memenangkan persaingan. Persaingan yang semakin meningkat membutuhkan strategi pemasaran tersendiri semakin penting.

Menurut Kotler dan Armstrong (2012:275), merek adalah nama, istilah, tanda, lambang atau desain, atau kombinasi dari semua ini yang memperlihatkan identitas produk atau jasa dari satu penjual atau sekelompok penjual dan membedakan produk itu dari produk pesaing. Minat Beli Menurut Kinnear dan Taylor (1995) dalam Cece (2015) minat beli adalah tahap kecenderungan responden dalam bertindak sebelum keputusan membeli benar-benar dilakukan.

\section{Pelayanan Purna Jual}

Sudarsono dan Edilius (2010) dalam Rifai dan Hening (2016) menyatakan tentang pelayanan purna jual adalah sebagai berikut: pelayanan purna jual atau after sale service sebagai jasa pelayanan yang meliputi perbaikan, penyediaan suku cadang, dan lain-lain yang diberikan oleh perusahaan kepada konsumen setelah produknya dibeli untuk jangka waktu tertentu. Pemberian pelayanan purna jual biasanya dilakukan sebagai suatu bentuk tanggung jawab yang diberikan oleh penjual atas barang yang telah mereka jual. Pelayanan ini 
diberikan dalam bentuk pemberian garansi, penggantian barang-barang rusak, pemeliharaan dan penyediaan suku cadang.

Sedangkan menurut Hindle dan Thomas dalam Tjiptono (2015: 32) layanan purna jual adalah suatu layanan yang disediakan oleh produsen kepada konsumen setelah konsumen tersebut membeli produk dari perusahaan tersebut. Kemudian Kotler dan Amstrong (2012:508) mengatakan bahwa layanan purna jual adalah sebagai berikut: layanan yang diberikan perusahaan kepada konsumen setelah terjadinya transaksi penjualan. Berdasarkan pengertian di atas dapat disimpulkan bahwa layanan purna jual adalah suatu kegiatan yang dilaksanakan setelah penyerahan produk kepada konsumen, yang berlaku selama konsumen masih ada ikatan layanan atau hubungan dalam berbagai kegiatan atas layanan perusahaan. Pelayanan purna jual dapat memastikan bahwa pelanggan puas dan dapat memperbaiki hubungan dan ketahanan pelanggan dalam situasi apapun. Hubungan perusahaan dengan pelanggan benar-benar menjadi lebih solid pada saat setelah terjadinya pembelian.

\section{Keputusan Pembelian Konsumen}

Keputusan pembelian konsumen merupakan suatu kegiatan individu yang secara langsung terlibat untuk mendapatkan (membeli) barang yang ditawarkan. Keputusan tersebut melibatkan pilihan di antara dua atau lebih alternatif tindakan atau perilaku, serta memutuskan membeli atau tidaknya sebuah produk (membeli/tidak membeli). Suatu keputusan (decision) melibatkan pilihan di antara dua atau lebih alternatif tindakan atau perilaku.

Menurut Setiadi

(2013:415) pengambilan keputusan konsumen adalah pengambilan keputusan konsumen (consumer decision making) adalah proses pengintegrasian yang mengkombinasikan pengetahuan untuk mengevaluasi dua atau lebih perilaku alternatif dan memilih salah satu diantaranya. Hasil dari pengintegrasian ini adalah pilihan (choice) yang disajikan secara kognitif sebagai keinginan berperilaku. Kotler dan Keller (2012:276) menyatakan bahwa keputusan pembelian adalah keputusan konsumen mengenai preferensi terhadap kumpulan merek-merek.

Menurut Peter Olson dalam Nitisusastro (2013:195) keputusan pembelian merupakan proses interaksi antara sikap afektif, sikap kognitif, sikap perilaku dengan faktor lingkungan dimana manusia melakukan pertukaran dalam semua aspek kehidupan. Keputusan pembelian konsumen menurut Sangadji dan Sopiah (2013:123) adalah proses pemecahan masalah yang diarahkan pada sasaran. Pemecahan masalah konsumen sebenarnya merupakan suatu aliran tindakan timbale balik yang berkesinambungan diantara faktor lingkungan, proses kognitif dan afektif serta adanya tindakan perilaku.

\section{Faktor-faktor Yang Mempengaruhi}

\section{Keputusan Pembelian Konsumen}

Menurut Buchari dalam Emor dan Agus (2015) adalah suatu keputusan konsumen yang dipengaruhi oleh ekonomi keuangan, teknologi, politik, budaya, produk, harga, lokasi, promosi, physical evidence, people dan process. 
Keputusan konsumen dipengaruhi oleh kualitas produk, sosial pribadi dan psikologis dari pembeli. Sebahagian besar adalah faktor-faktor yang tidak dapat dikendalikan oleh pemasar, tetapi benar-benar di perhitungkan. Faktor-faktor tersebut secara lebih rinci menurut Setiadi (2013:11) adalah faktor kebudayaan, saluran distribusi, pribadi dan kualitas produk dan saluran distribusi. Faktor-faktor yang mempengaruhi keputusan pembelian konsumen menurut Kotler dan Keller (2012:283) dimulai dari lingkungan yang umum ke yang khusus meliputi peran pribadi dan psikologis.

Menurut Charles et al (2013:198) proses pengambilan keputusan ketika akan melakukan pembelian bervariasi dari satu konsumen dan konsumen lainnya. Ada tiga bentuk keputusan konsumen berdasarkan keterlibatan adalah perilaku respon rutin (routine response behavior), Pengambilan keputusan yang terbatas (limited decision making), Pengambilan keputusan yang ekstensif (extensive decision making).

Menurut Zeitham dan Bitner (2000) dalam Hurriyati (2010:55) ada beberapa indikasi dari keputusan pembelian antara lain mencakup pencarian sumber-sumber informasi, penilaian berbagai alternative, pembelian dan penggunaan, dan evaluasi pasca pembelian.

\section{METODE PENELITIAN}

Penelitian ini dilaksanakan di Kota Banda Aceh. Objek penelitian adalah persepsi kualitas produk, merek, layanan purna jual, dan keputusan pembelian skuter metik merek Honda. Disamping itu juga disajikan beberapa informasi lainnya mengenai gambaran umum konsumen merek Honda di Kota Banda Aceh.

Populasi penelitian adalah seluruh konsumen pemilik sepeda motor merek Honda di Kota Banda Aceh. Pada tahun 2017, konsumen sepeda motor merek Honda tercatat sebanyak 7.909 konsumen (PT. Capella Dinamika Nusantara Banda Aceh Cabang Peunayong). Jumlah sampel penelitian adalah sebanyak 381 konsumen. Penarikan sampel dalam penelitian ini dilakukan dengan formulasi sampel minimal dengan menggunakan metode Slovin dan Sevila (Suwarno, 2012:55) dengan Tingkat kepercayaan/ketepatan yang diinginkan $(95 \%=$ $0,05)$.

Pengumpulan data dilakukan dengan cara membagikan daftar kuesioner yang telah dipersiapkan kepada konsumen. Daftar kuesioner berisikan pertanyaanpertanyaan tentang identitas responden, persepsi kualitas produk, merek, layanan purna jual dan keputusan pembelian konsumen. Kuesioner yang digunakan dalam penelitian ini adalah tertutup yaitu pertanyaan yang dirancang berbentuk pilihan.

Pengujian dan analisis data primer dilakukan dengan menggunakan perangkat SPSS Versi 12 dengan formulasi regresi linier berganda menurut Sugiyono (2014:277) adalah sebagai berikut :

$$
\mathrm{Y}=\mathrm{a}+\mathrm{b}_{1} \mathrm{X}_{1}+\mathrm{b}_{2} \mathrm{X}_{2}+\mathrm{b}_{3} \mathrm{X}_{3}+\mathrm{e}
$$

Di mana :

$$
\begin{aligned}
& \mathrm{Y}=\text { Keputusan Pembelian } \\
& \alpha=\text { Konstanta } \\
& \mathrm{X}_{1}=\text { Persepsi kualitas produk }
\end{aligned}
$$




$$
\begin{aligned}
& \mathrm{X}_{2}=\text { Merek } \\
& \mathrm{X}_{3}=\text { Layanan Purna Jual } \\
& \mathrm{b}_{1}, \mathrm{~b}_{2}, \mathrm{~b}_{3} \text {, = Koefisien regresi } \mathrm{X}_{1} \text { dan } \mathrm{X}_{2} \\
& e \quad=\text { Error term }
\end{aligned}
$$

\section{HASIL DAN PEMBAHASAN}

\section{Karakteristik Responden}

Konsumen yang menjadi responden dalam penelitian ini adalah masyarakat yang membeli dan memiliki skuter metik merek Honda yang ditemui di sejumlah sentra pelayanan purna jual PT.Capella di Kota Banda Aceh. Konsumen tersebut berasal dari berbagai kalangan baik mahasiswa, PNS, karyawan swasta maupun wiraswasta. Mereka terpilih sesuai dengan jumlah sampel yang telah ditetapkan yaitu sebanyak 381 orang.

Konsumen tersebut memiliki tingkat umur, jenis kelamin, status, Pendidikan, dan status pekerjaan. Perbedaan karateristik sosial dan demografi tersebut ini akan menyebabkan berbedanya perilaku pembelian mereka. Dari 381 konsumen pengguna skuter metik merek Honda yang terdata dan memanfaatkan pelayanan purnal jual pada PT. Capella di Kota Banda Aceh. Sebahagian besar atau sebanyak 30,2\% berumur antara 20-25 tahun. Kemudian sebanyak $17,8 \%$ berumur antara 31-35 tahun. Ada 3,1\% dari jumlah konsumen dengan umur antara 41-45 tahun dan 18,6\% berumur kurang dari 20 tahun. Selebihnya 17,8\% dari jumlah konsumen yang membeli atau menggunakan skuter metik merek Honda di Kota Banda Aceh berumur antara 31-35 tahun. Adapun konsumen yang menggunakan skuter metik merek Honda di Kota Banda Aceh sebahagian besar atau sebanyak 53,0\% berjenis kelamin perempuan. Selebihnya $47,0 \%$ berjenis kelamin laki- laki.

Dilihat dari pendidikan terakhir, sebahagian besar atau 55,9 dari jumlah konsumen yang menggunakan skuter metik merek Honda di Kota Banda Aceh adalah mereka dengan tingkat pendidikan SLTA. Kemudian sebanyak $31,8 \%$ dari jumlah konsumen yang menggunakan skuter metik merek Honda di Kota Banda Aceh adalah mereka dengan tingkat pendidikan S1. Adapun $8,4 \%$ dari jumlah konsumen dengan tingkat pendidikan S2. Selebihnya 3,9\% dari jumlah konsumen yang menggunakan skuter metik merek Honda di Kota Banda Aceh adalah mereka dengan tingkat pendidikan DIII.

Konsumen yang menggunakan skuter metik merek Honda di PT.Capella Dinamika Nusantara di Kota Banda Aceh sebahagian besar atau sebanyak $32,0 \%$ berstatus sebagai mahasiswa dan $29,1 \%$ dari jumlah konsumen berstatus sebagai PNS. Ada 16,8\% dari jumlah konsumen yang terdata merupakan pelajar. Selebihnya $10,5 \%$ dan $11,5 \%$ dari jumlah konsumen yang menggunakan skuter metik merek Honda di PT.Capella Dinamika Nusantara di Kota Banda Aceh adalah wiraswasta dan karyawan swasta.

Dilihat dari tingkat pendapatan, konsumen yang menggunakan skuter metik merek Honda di Kota Banda Aceh sebahagian besar atau sebanyak $29,1 \%$ dengan pendapatan antara Rp.3.100.000-4.000.000 dan 26,8\% dari jumlah konsumen dengan pendapatan antara Rp.1.000.000-2.000.000. Ada 5,2\% dari jumlah 
konsumen yang terdata dengan pendapatan antara Rp 4.100.000-5.000.000 dan 22,0\% dengan pendapatan <Rp.1.000.000. Selebihnya $16,8 \%$ dari jumlah konsumen yang menggunakan skuter metik merek Honda di Kota Banda Aceh dengan pendapatan antara Rp.2.100.000-3.000.000.

Pengaruh Persepsi Kualitas Produk, Merek dan Layanan Purna Jual Terhadap Keputusan Pembelian

Pengaruh variabel bebas terhadap variabel terikat dapat dibuktikan dengan analisis regresi berganda (multiple regression). Analisis ini bertujuan untuk memprediksi sejauhmana tingkat kenaikan interval dari 3 (tiga) variabel bebas yang terlibat dalam penelitian ini yaitu Persepsi kualitas produk $\left(\mathrm{X}_{1}\right)$, merek $\left(\mathrm{X}_{2}\right)$ dan layanan purna jual $\left(\mathrm{X}_{3}\right)$ terhadap kenaikan variabel terikat yaitu keputusan pembelian (Y) pada tingkat kesalahan tertentu (significansi) atau dimana pengaruh antar variabel tersebut benar-benar nyata. Hasil output SPSS regresi linier berganda pengaruh variabel bebas dan terikat dapat dilihat Tabel 1.

Tabel 1. Hasil Analisis Model Regresi Pengaruh Persepsi Kualitas Produk, Merek Dan Layanan Purna Jual Terhadap Keputusan Pembelian

\begin{tabular}{|l|c|c|c|}
\hline \multirow{2}{*}{ Model } & \multicolumn{2}{|c|}{$\begin{array}{l}\text { Unstandardized } \\
\text { Coefficients }\end{array}$} & $\begin{array}{c}\text { Standardized } \\
\text { Coefficients }\end{array}$ \\
\cline { 2 - 4 } & $B$ & Std. Error & Beta \\
\hline (Constant) & 1.041 & 0.303 & \\
\hline $\begin{array}{l}\text { Persepsi } \\
\text { kualitas } \\
\text { produk }\end{array}$ & 0.264 & 0.052 & 0.211 \\
\hline Merek & 0.641 & 0.062 & 0.434 \\
\hline $\begin{array}{l}\text { Layanan } \\
\text { purna jual }\end{array}$ & 0.326 & 0.056 & 0.242 \\
\hline
\end{tabular}

Dari hasil output SPSS pada Tabel 1 di atas dapat dibuat garis persamaan linier adalah sebagai berikut:

$$
\mathrm{Y}=1.041+0,264 \mathrm{X}_{1}+0,641 \mathrm{X}_{2}+0,326 \mathrm{X}_{3}
$$

Persamaan di atas menjelaskan sebagai berikut:

1. Nilai konstanta keputusan pembelian sebesar 1,041 menjelaskan jika persepsi kualitas produk $\left(\mathrm{X}_{1}\right)$, merek $\left(\mathrm{X}_{2}\right)$ dan layanan purna jual $\left(\mathrm{X}_{3}\right)$ tidak mengalami perubahan, maka keputusan pembelian skuter metik merek Honda di Kota Banda Aceh secara konstan berada pada posisi 1,041 unit skala likert. Kondisi ini menandakan tingkat keputusan pembelian di Kota Banda Aceh masih tergolong rendah.

2. Koefisien regresi pengaruh persepsi kualitas produk kerja sebesar 0,264, menjelaskan setiap terjadinya kenaikan satu unit skala likert kualitas produk skuter metik merek Honda maka akan dapat meningkatkan keputusan pembelian konsumen sebesar 0,264 unit skala likert. Dengan demikian dapat dikatakan bahwa jika persepsi kualitas produk meningkat maka keputusan pembelian skuter metik merek Honda di Kota Banda Aceh juga akan semakin baik.

3. Koefisien regresi pengaruh merek sebesar 0,641 menjelaskan setiap adanya kenaikan satu unit skala likert variabel merek maka akan dapat 
meningkatkan keputusan pembelian di Kota Banda Aceh sebesar 0,641 unit skala likert. Dengan demikian dapat dikatakan bahwa jika merek dapat ditingkatkan maka keputusan pembelian di Kota Banda Aceh akan semakin baik.

4. Koefisien regresi pengaruh layanan purna jual sebesar 0,326 menjelaskan setiap terjadinya kenaikan satu unit skala likert variabel layanan purna jual maka akan dapat meningkatkan keputusan pembelian sebesar 0,326 unit skala likert. Dengan demikian dapat dikatakan bahwa jika layanan purna jual dapat ditingkatkan maka keputusan pembelian di Kota Banda Aceh akan semakin baik.

\section{Koefisien Korelasi dan Determinasi}

Pengaruh linier antara Persepsi kualitas produk, layanan purna jual, dan merek skuter metik dengan keputusan pembelian memiliki hubungan dapat dibuktikan dengan koefisien korelasi dan koefisien determinasi. Koefisien ini menjelaskan keeratan hubungan keseluruhan variabel bebas secara serentak dengan variabel tak bebas. Nilai korelasi bergerak antara -1 sampai dengan +1 dan semakin mendekati nilai 1 atau sama dengan 1 maka korelasi antara variabel akan semakin kuat atau sebaliknya. Sedangkan koefisien determinasi adalah suatu koefisien yang menjelaskan besarnya pengaruh secara serentak variabel-variabel bebas terhadap variabel terikatnya. Kemudian dari hasil korelasi dapat diketahui hasil korelasi determinasi $\left(\mathrm{R}^{2}\right)$ yang menjelaskan sejauhmana kontribusi hubungan satu variabel dengan variabel lainnya.

Koefisien korelasi $\mathrm{R}$ sebesar 0,622 menjelaskan terdapat hubungan yang positif antar variabel bebas meliputi persepsi kualitas produk (X1), merek (X2) dan layanan purna jual (X3) dengan keputusan pembelian (Y) di Kota Banda Aceh, hubungan tersebut tergolong kuat dengan keeratan hubungan 0,622 atau 62,2\%.

Koefisien determinasi Adjusted R Square sebesar 0.386 menjelaskan, peran variabel persepsi kualitas produk (X1), merek (X2) dan layanan purna jual (X3) dalam mempengaruhi keputusan pembelian (Y) di Kota Banda Aceh adalah sebesar 0.386 atau 38,60\%. Sementara sisa (nilai residu) dari peran variabel tersebut sebesar 0,614 atau $61,4 \%$ dipengaruhi oleh variabel lainnya yang tidak dilibatkan dalam penelitian ini.

\section{Pembuktian Hipotesis}

\section{Uji F (Simultan)}

Hasil pembagian Mean Square diperoleh nilai $\mathrm{F}$ hitung sebesar 25,467 pada batasan tingkat signifikansi 0,000 . Sementara nilai $F$ tabel taraf signifikan \% dan df 59 adalah sebesar 3,17. Dengan demikian terlihat bahwa nilai $F$ hitung (79.162) > F tabel $(3,17)$ sehingga hipotesis Ha yang menyatakan Persepsi kualitas produk (X1), merek (X2) dan layanan purna jual (X3) berpengaruh secara signifikan terhadap keputusan pembelian (Y) di Kota Banda Aceh dapat diterima kebenarannya.

\section{Uji t (Parsial)}

Uji ini dilakukan untuk melihat 
signifikan dari pengaruh variabel independen secara individu terhadap variabel dependen (secara parsial). Dengan menganggap variabel lainnya konstan. Bila $\mathrm{t}$ hitung $>\mathrm{t}$ tabel dengan signifikansi 5\% maka dapat disimpulkan bahwa secara parsial variabel independen berpengaruh signifikan terhadap variabel dependen. Jika $\mathrm{t}$ hitung < ttabel dengan tingkat signifikansi 5\% maka dapat disimpulkan variabel independen tidak berpengaruh terhadap dependen.

Pengaruh dari masing-masing variabel adalah:

a. Hasil analisis pengaruh persepsi kualitas produk terhadap keputusan pembelian skuter metik merek Honda di Kota Banda Aceh Dari hasil analisis SPSS diperoleh nilai t hitung untuk variabel persepsi kualitas produk sebesar 5,085 pada batasan nilai probabilitas 0,000 . Sementara nilai $t$ tabel pada tingkat kesalahan 5\% adalah 1,900. Dengan demikian $\mathrm{t}$ hitung $>\mathrm{t}$ tabel sehingga $\mathrm{Ha}$ diterima, artinya persepsi kualitas produk berpengaruh terhadap keputusan pembelian skuter metik merek Honda di Kota Banda Aceh.

b. Hasil analisis pengaruh merek terhadap keputusan pembelian skuter metik merek Honda di Kota Banda Aceh Dari hasil analisis SPSS diperoleh nilai t hitung untuk variabel merek sebesar 10,409 pada batasan nilai probabilitas 0,000 . Sementara nilai $\mathrm{t}$ tabel tingkat kesalahan 5\% adalah 1,900. Dengan demikian $\mathrm{t}$ hitung $>\mathrm{t}$ tabel sehingga hipotesis Ha, artinya merek skuter metik berpengaruh terhadap keputusan pembelian skuter metik merek Honda di Kota Banda Aceh. dapat diterima kebenarannya.
Secara lebih rinci, hasil uji f dan uji t dapat dilihat pada Tabel 2.

Tabel 2. Ringkasan Pengujian Hipotesis

\begin{tabular}{|l|c|c|c|}
\hline \multirow{2}{*}{$\begin{array}{c}\text { Bentuk } \\
\text { Pengujian }\end{array}$} & \multicolumn{2}{|c|}{ Nilai Statistik } & \multirow{2}{*}{ Keterangan } \\
\cline { 2 - 3 } $\begin{array}{l}\text { Pengujian } \\
\text { secara simultan }\end{array}$ & 79.162 & 3,17 & $\begin{array}{l}\text { Ketiga variabel } \\
\text { berpengaruh } \\
\text { signifikan (hipotesis } \\
\text { Ha diterima). }\end{array}$ \\
\hline $\begin{array}{l}\text { Pengujian } \\
\text { secara parsial }\end{array}$ & $\mathrm{t}_{\text {hitung }}$ & $\mathrm{t}_{\text {tabel }}$ & \\
\hline $\begin{array}{l}\text { Persepsi } \\
\text { kualitas produk } \\
\left(\mathrm{X}_{1}\right)\end{array}$ & 0.211 & 1,984 & $\begin{array}{l}\text { Persepsi kualitas } \\
\text { produk berpengaruh } \\
\text { signifikan }\end{array}$ \\
\hline $\begin{array}{l}\text { Merek }\left(\mathrm{X}_{2}\right) \\
\text { Layanan purna }\end{array}$ & 0.434 & 1,984 & $\begin{array}{l}\text { Merek berpengaruh } \\
\text { signifikan }\end{array}$ \\
\hline jual $\left(\mathrm{X}_{3}\right)$ & 1,984 & $\begin{array}{l}\text { Layanan purna jual } \\
\text { berpengaruh } \\
\text { signifikan }\end{array}$ \\
\hline
\end{tabular}

Sumber: Data Primer (Diolah), 2018

\section{KESIMPULAN DAN SARAN}

\section{Kesimpulan}

Berdasakan hasil penelitian yang telah diperoleh, maka dapat disimpulkan beberapa kesimpulan adalah:

Persepsi kualitas produk berpengaruh secara signifikan terhadap keputusan pembelian skuter metik merek Honda di Kota Banda Aceh. Dengan demikian jika persepsi kualitas produk di Kota Banda Aceh meningkat maka keputusan pembelian konsumen akan lebih baik.

Merek skuter metik berpengaruh secara signifikan terhadap keputusan pembelian skuter metik merek Honda di Kota Banda Aceh. Dengan demikian jika persepsi kualitas merek skuter metik di Kota Banda Aceh meningkat maka keputusan pembelian konsumen akan lebih baik.

Layanan purna jual berpengaruh secara signifikan terhadap keputusan pembelian skuter metik merek Honda di Kota Banda Aceh. Dengan demikian jika layanan purna jual di Kota Banda Aceh dapat ditingkatkan maka 
keputusan pembelian konsumen akan lebih baik.

Secara simultan persepsi kualitas produk, merek, dan layanan purna jual memiliki hubungan yang kuat dan positif dengan keputusan pembelian skuter metik merek Honda di Kota Banda Aceh di Kota Banda Aceh.

Peran persepsi kualitas produk, merek, dan layanan purna jual dalam mempengaruhi keputusan pembelian skuter metik merek Honda di Kota Banda Aceh masih kurang dominan. Dengan demikian masih banyak variabel lainnya yang ikut mempengaruhi keputusan pembelian pada PT.Capella Banda Aceh.

\section{Saran}

Terkait beberapa temuan kelemahan dari hasil penelitian, maka penulis menyarankan:

1. Kenyamanan penggunaan skuter metik merek Honda perlu ditingkatkan.

2. Layanan garansi service perlu dilakukan secara lebih teliti dan tidak terburu-buru untuk mengejar target sehingga dapat memberi peluang bagi konsumen dalam menjaga kualitas mesin skuter metik Honda secara berkala.

\section{DAFTAR PUSTAKA}

Cece, I. Sen. (2015). Pengaruh Brand Origin, Brand Ambassador Dan Merek Terhadap Minat Beli Sepatu Macbeth Di Sogo Galaxy Mall Surabaya. Fakultas Ekonomi \& Bisnis Universitas Narotama Surabaya. e-Jurnal Manajemen Kinerja. l(2).

Charles Lamb, W.et.al. (2013). Pemasaran.

Edisi Pertama. Salemba Empat: Jakarta.
Emor Y.S Rizky., Supandi Agus. (2015). Pengaruh Potongan Harga, Merek, dan Servicescape Terhadap Keputusan Pembelian Konsumen Indomaret Tanjung Batu. Jurnal Emba. 3(2).

Hurriyati. (2010). Bauran pemasaran dan Loyalitas Konsumen, Penelitian Pada Kartu Kredit Perbankan.

Kotler, Philip., Kevin L. Keller. (2012). Manajemen Pemasaran. Jakarta: Erlangga.

Kotler, Philip., Amstrong. (2012). Prinsipprinsip Pemasaran. Jakarta: Erlangga.

Nitisusastro. (2012). Perilaku Konsumen:

Dalam Perspektif Kewirausahaan.

Bandung: Alfabeta.

Rifai, A. Iman., Hening W. Oetomo. (2016). Pengaruh Produk Dan Layanan Purna Jual Terhadap Keputusan Pembelian Motor Honda. Jurnal Ilmu dan Riset Manajemen Sekolah Tinggi Ilmu Ekonomi Indonesia (STIESIA) Surabaya, 5(3).

Sangadji E. Mamang., Sopiah. (2013). Perilaku Konsumen. Yogyakarta: Andi

Setiadi N. J. (2013). Perilaku Konsumen: Konsep dan Implikasi Untuk Strategi dan Penelitian Pemasaran. Jakarta : Kencana. Sugiyono (2014). Metode Penelitian Kunatitatif Kualitatif dan $R \& D$. Bandung:Alfabeta.

Sunyoto, Danang. (2012). Dasar-dasar Manajemen Pemasaran Konsep Srategi dan Kasus. CAPS, Yogyakarta.

Sumarwan, Ujang. (2015). Perilaku Konsumen

Teori Penerapannya Dalam Pemasaran Edisi Kedua. Cetakan Ketiga. Bogor: Penerbit Ghalia Indonesia. 
Suwarno, Jonathan. (2010). Riset Akuntansi

Dengan Menggunakan SPSS,

Jakarta:Graha Ilmu.

Tjiptono Fandy. (2014). Strategi Pemasaran.

Yogyakarta :Andi.

Tjiptono, Fandy (2015). Manajemen Pemasaran

Jasa. Jakarta: Andi.

Yusuf Mohammad. (2015). Pengaruh Kualitas

Produk, Kebijakan Harga, dan Saluran

Distribusi Terhadap Kepuasan Konsumen

Pembelian Sperpart Variasi dan

Pemasangan Di CV Prima Ac. Jurnal

Ilmiah Program Studi Manajemen

Fakultas Ekonomi Universitas Nusantara

PGRI Kediri.

- How to cite this paper :

Jufidar, J., Abbas, F., \& Safwadi, I. (2019).

Pengaruh Persepsi Kualitas Produk,

Merek dan Layanan Purna Jual Terhadap

Keputusan Pembelian Skuter Metik

Merek Honda di Kota Banda Aceh. Jurnal

Humaniora, 3(1), 14-25. 